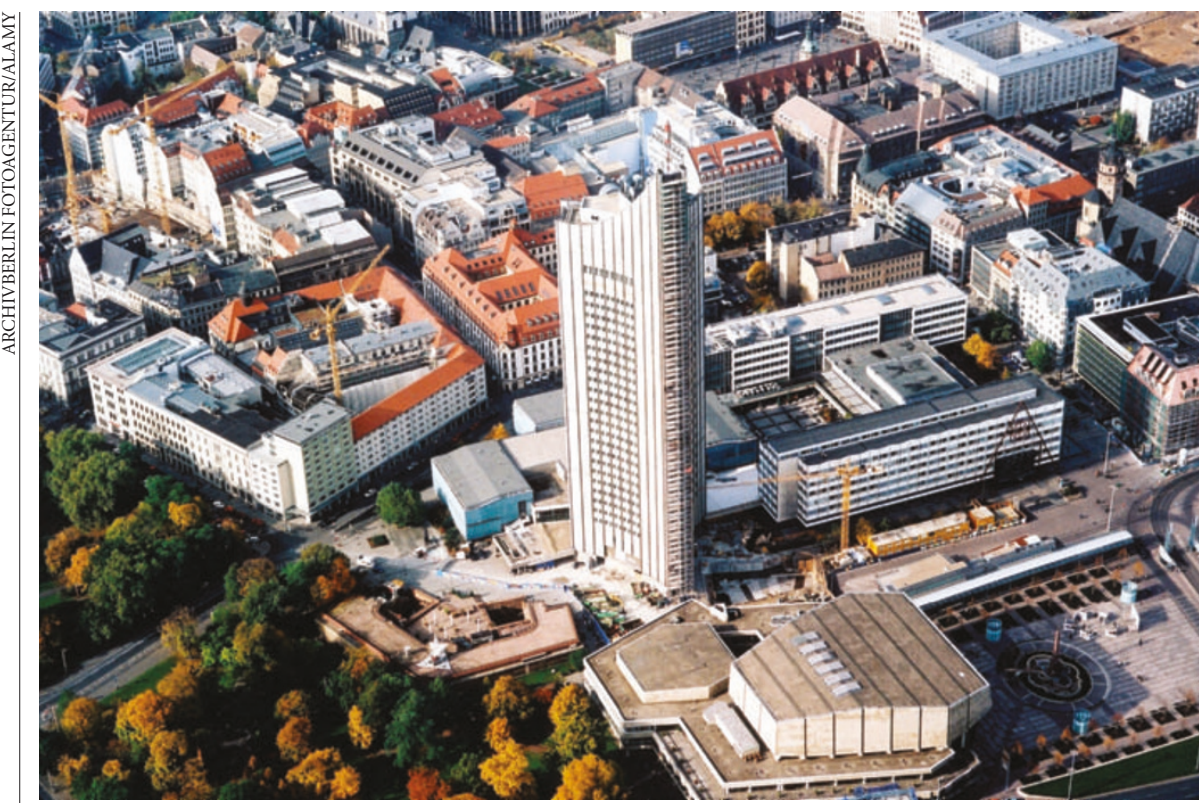

Caught in the crossfire: universities such as Leipzig may miss the chance to compete for extra money.

\title{
Political wrangling derails German university reforms
}

Quirin Schiermeier, Munich

An ambitious attempt to reward Germany's top universities looks set to fall victim to squabbling between the country's main political parties.

At a meeting on 5 July, the federal government and Germany's 16 Länder (states) failed to agree how to implement a competition to identify and reward the country's best universities. The $€ 1$.9-billion (US\$2.4-billion) programme is now on ice until November, when attempts will be made to renegotiate it. But after last week's unexpected failure, observers fear that this may never happen.

In Germany there is frequent wrangling between the federal government, controlled by a coalition of Social Democrats and Greens, and the states, mostly ruled by the Christian Democrats, which must approve most new laws. The power tussles thwart attempts at reform, and have been branded the 'German disease'.

Now science policy has caught the malaise. In February, Edelgard Bulmahn, the federal research minister, announced plans for a competition to start this summer. From 2006 to 2010, up to ten universities were to receive an extra $€ 50$ million each year for hiring top scientists, modernizing labs, and improving research and education (see Nature 427, 477; 2004). The effort was supposed to meet concerns that the German university budget is too thinly spread, and help a few élite institutions to compete internationally.

The Länder wanted to become involved, and agreed to contribute a quarter of the money. But at last week's meeting, they made demands that could derail the idea. States controlled by Christian Democrats sought to delay the competition until their responsibilities for the universities have been clarified. A special commission is looking into the responsibilities of the federal and state governments, but it is unlikely to report soon (see Nature 423, 790; 2003).

"Bulmahn's wish to press ahead with the competition is politically motivated," says Peter Frankenberg, the science minister of the state of Baden-Württemberg in southern Germany. Like other Christian Democrats, he insists that there should be no time pressure to act.

In a 7 July statement, the 81 member institutions of the DFG, Germany's main grant-giving agency, called on policy-makers to settle their differences and get the competition moving. "Top university research in Germany needs extra funding to compete on a global stage," the statement said.

"There was a lot of enthusiasm here, and we reckoned on having a good chance of winning," says Franz Häuser, rector of the University of Leipzig. "Our best scientists have been busy for months preparing for the competition. Stopping the train at this point sends a highly disturbing political signal."

Now, Germany's cash-starved universities will have to wait for their bonuses. "It's the same old story," says Jürgen Mlynek, president of the Humboldt University in Berlin. "Everyone agrees on the content, but no one is prepared to agree politically."
Funding not keeping pace with science, warns Pasteur chief

Declan Butler, Paris

The Pasteur Institute - France's most prestigious private biology laboratory is facing a financial crunch, warns its director-general, Philippe Kourilsky.

The institute, which employs about 2,500 staff studying microbiology and infectious diseases, says that public support for its researchers isn't keeping pace with its expanding activities. Over the past decade, says Kourilsky, income from contracts and patents has risen by about $40 \%$ to $€ 45$ million (US\$56 million) last year. Funds from donations and endowments rose by $70 \%$ to almost $€ 60$ million. The share of the budget met by public funding has plummeted to less than one-third.

"It's absolutely unfair," complains Kourilsky. "We do top science, and for every euro the government gives us, we generate two." The institute's scientific output far exceeds its $3.5 \%$ share of the French budget for life sciences, he says.

Kourilsky blames lagging public investment for the institute facing a $€ 24$ million shortfall in its $€ 185$-million budget for 2003. The institute expects to break even this year thanks to some large contracts - but Kourilsky says that he anticipates deficits in years to come.

The French government has strayed from a tacit agreement that public funding should cover about half of the institute's costs, he says. A scienceministry spokesman says that it is aware of the problem. He says that the government intends to provide "bonus funding" for some of France's top research centres next year.

During a previous financial crisis in 1965, Charles de Gaulle, then president of France, came to the institute's aid, saying that it was "as untouchable as the Eiffel Tower". But institute officials are less optimistic about being bailed out by the current president, Jacques Chirac.

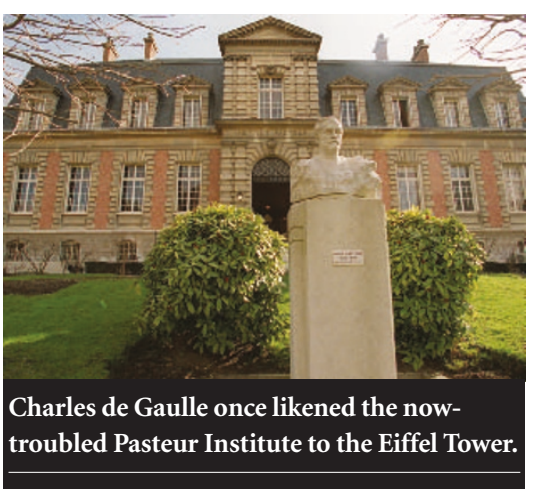

